[Original]

\title{
The Effect of D-Cycloserine on Spatial Learning Performance and Memory Function-Related Gene Expression in Mice Following Toluene Exposure
}

\author{
Tin-Tin Win-Shwe ${ }^{1}$, Shiho KageYama ${ }^{1}$, Shinji Tsukahara ${ }^{2}$, Daisuke NakaJima ${ }^{1}$ and \\ Hidekazu FumMAKI ${ }^{1 *}$ \\ ${ }^{1}$ Research Center for Environmental Risk, National Institute for Environmental Studies, 16-2 \\ Onogawa, Tsukuba, Ibaraki 305-8506, Japan \\ ${ }^{2}$ Department of Regulation Biology Graduate School of Science and Engineering Saitama \\ University, 255 Shimo-Okubo, Sakura-ku, Saitama City, Saitama 338-8570, Japan
}

Abstract : D-cycloserine (DCS), a partial N-methyl-D-aspartate (NMDA) receptor agonist, is a well-known cognitive enhancer. To investigate the effect of DCS in cognitive function following toluene exposure, eight-week-old male $\mathrm{C} 3 \mathrm{H} / \mathrm{HeN}$ mice were exposed to filtered air $(0 \mathrm{ppm})$ or $50 \mathrm{ppm}$ toluene for $6 \mathrm{~h}$ a day on 5 consecutive days a week for 6 weeks. The day after the day of final exposure, a spatial learning task was performed using a Morris water maze apparatus. During the learning task, some mice were treated with DCS intraperitoneally (20 $\mathrm{mg} / \mathrm{kg}$ ) $30 \mathrm{~min}$ before the first trial of the acquisition phase and probe trial. After completion of the spatial learning task, the hippocampus was collected from each mouse to examine memory function-related gene expression using the real-time RT-PCR method. During the acquisition phase, on day 3 and 4, toluene-exposed mice with DCS treatment showed significantly better learning performance than corresponding saline treated groups. Moreover, the toluene-exposed mice with DCS treatment also showed significantly improved memory retention during the probe trial and up-regulation of hippocampal NMDA receptor subunit $2 \mathrm{~B}$ mRNA expression compared with the saline treated groups. Our findings indicate that a subunit-specific modulation of hippocampal NMDA receptor mRNA expression by DCS contributes to improvement of spatial learning performance in mice following toluene exposure.

Key words : toluene, NMDA receptor, learning performance, hippocampus.

(Received 25 January 2010, accepted 26 April 2010)

* Corresponding author: Hidekazu Fujmaki, Ph.D., Research Center for Environmental Risk, National Institute for Environmental Studies, 16-2 Onogawa, Tsukuba, Tbaraki 305-8506, Japan, Tel: +81-29-850-2518, Fax: +81-29-8502518,E-mail: fujimaki@nies.go.jp 


\section{Introduction}

Environmental chemicals are one of the causative factors of neurobehavioral disturbances. Among the environmental chemicals, toluene belongs to a large class of volatile organic compounds, and it targets the central nervous system, especially the hippocampus [1-3]. Toluene is one of the well known neurotoxic chemicals affecting memory functions. The occupational exposure limit for toluene is $50 \mathrm{ppm}$ in Japan [4], and the recently updated threshold limit value is $20 \mathrm{ppm}$ in United States [5]. Many reports have indicated that inhalation of low concentrations of toluene induces central neurological abnormalities in humans $[6,7]$ and a persistent deficit in spatial learning and memory in animals $[8,9]$. Learning behavior is one of the higher brain functions, and the hippocampus is one of the brain areas important for learning and memory. Previously, we have reported that 12 weeks exposure of $\mathrm{C} 3 \mathrm{H} / \mathrm{HeN}$ female mice to $50 \mathrm{ppm}$ toluene caused a significant up-regulation of N-methyl-D-aspartate (NMDA) receptor subunit 2B (NMDA NR2B) expression associated with a simultaneous induction of calcium/ calmodulin-dependent protein kinase (CaMK)-IV, cyclic AMP-responsive element binding protein (CREB)-1, and FosB/DeltaFosB in the same hippocampal tissues [10]. Moreover, our laboratory has also showed that NMDA NR2A, CaMKIV, CREB1, and BDNF were significantly up-regulated in the hippocampi of BALB/c wild type mice exposed to $9 \mathrm{ppm}$ of toluene in noseonly exposure chamber for $30 \mathrm{~min}$ on 3 consecutive days followed by weekly sessions for 4 weeks [11]. However, the precise mechanisms underlying the neurotoxic action of toluene are still debated.

Ionotropic glutamate receptors consist of the NMDA, alpha-amino-3-hydroxy-5-methylisoxazole4-propionic acid (AMPA), and kainite receptor families. Among these receptor families, NMDA receptors are heteromers composed of an NR1 subunit and one or more of the four NMDA receptor subunit 2 (NR2) subunits (NR2A-NR2D) [12,13]. For receptor activation, NMDA receptors not only require a synaptically released neurotransmitter glutamate, but also require the obligatory coagonist, glycine [14,15]. Electrophysiological studies have demonstrated that NMDA receptor activation requires the occupation of two independent glycine sites and two independent glutamate sites [16].

D-cycloserine (DCS) is a broad spectrum antibiotic presently approved as an adjunctive agent in the treatment of susceptible gram positive or negative bacteria and Mycobacterium tuberculosis. The antidepressant activities of DCS were first described in depressed tuberculosis patients showing improvement in mood [17]. DCS has a high affinity for the glycine binding site in the NMDA receptor complex and it modulated memory processing in a dose dependent manner [18] and it has attracted interest for its potential to enhance NMDA-mediated learning and memory tasks [19]. The aim of our study was to investigate the role of DCS, a partial NMDA receptor agonist, on the spatial learning performance and NMDA receptor subunit expressions in the hippocampus of mice following toluene exposure. This is the first study to show the effects of DCS on hippocampus-dependent cognitive function following environmental toxic chemical exposure. 
A, Exposure chamber

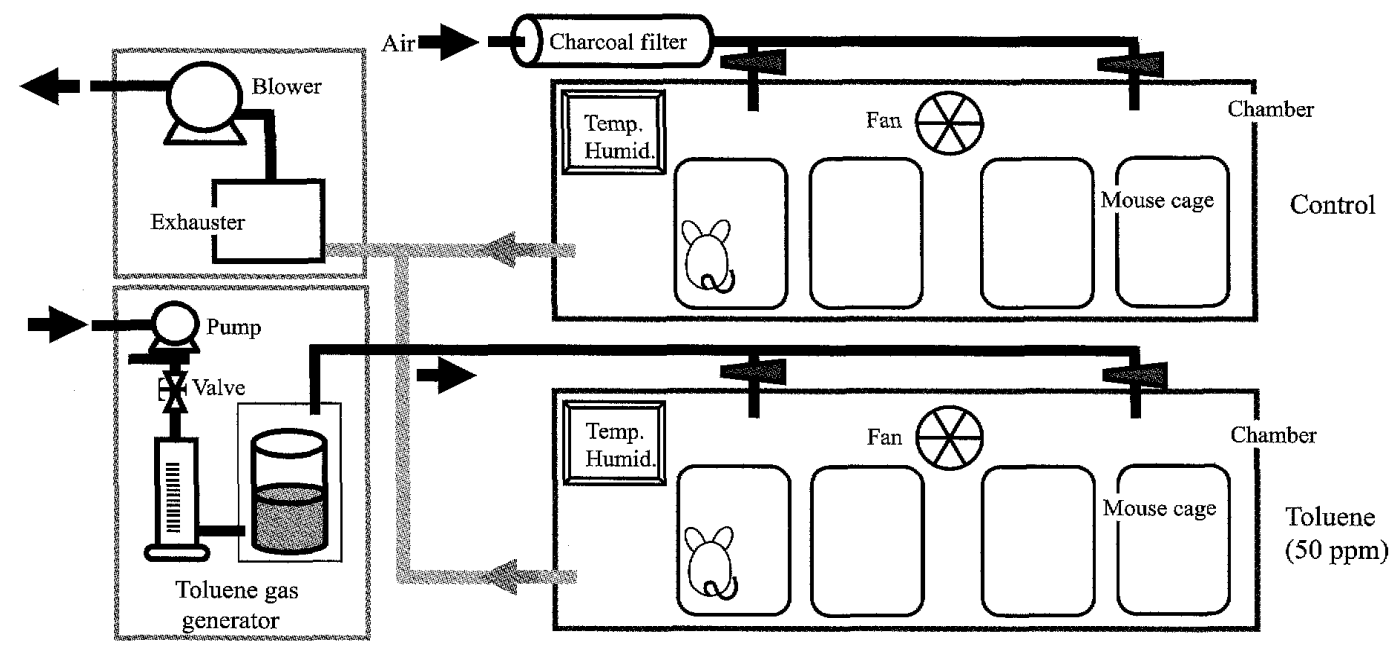

B, Experimental schedule

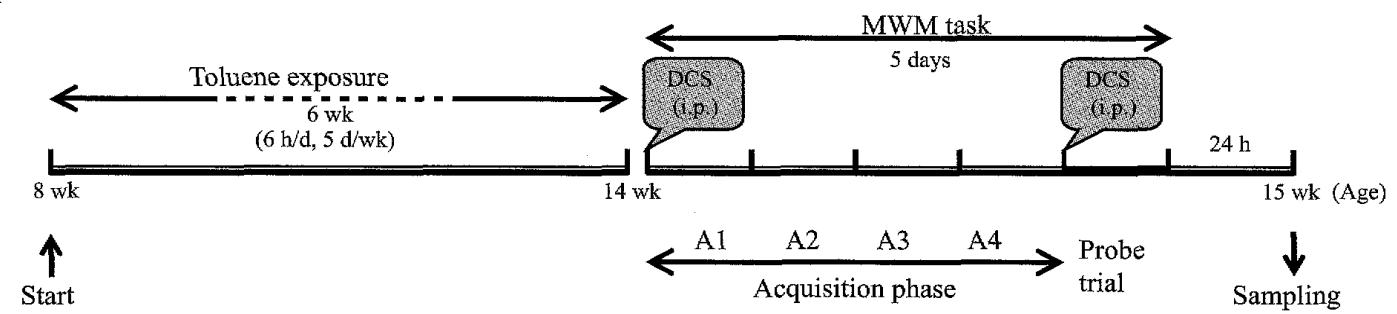

Fig. 1. A scheme of generation and exposure of toluene. A: Exposure chamber, and B: experimental schedule for toluene exposure and DCS treatment.

\section{Materials and Methods}

\section{Animals}

Male C3H/HeN mice ( 7 weeks old) were purchased from Charles River Japan Inc (Tokyo, Japan). At the age of 8 weeks, mice were recruited in the experiments. The mice were housed in cages under controlled environmental conditions (temperature $23 \pm 0.5^{\circ} \mathrm{C}$, humidity $50 \pm$ $5 \%$, lights on 07:00 - 19:00 h). The experiments were conducted under the control of the Ethics Committee of Animal Care and Experimentation of the National Institute for Environmental Studies, Japan.

\section{Generation of toluene}

Toluene vapor was generated by a Permeater Standard Gas Generation System (PD-1B, GASTEC Co., Kanagawa, Japan) and then introduced into acrylic chambers (Fig. 1A). An activated charcoal column was used between the compressor and permeater to remove organic compounds. Inside the chamber, $\mathrm{CaCl}_{2}, \mathrm{NaOH}$ and $\mathrm{H}_{3} \mathrm{PO}_{4}$ were added to remove water, $\mathrm{CO}_{2}$ and ammonia, respectively. The airflow rate through the chamber housing the experimental 
animals was $2 \mathrm{l} / \mathrm{min}$. The concentration of toluene in the chambers was measured at $30 \mathrm{~min}$ intervals using gas chromatography mass spectrometry (Hapsite; Inficon, East Syracuse, NY, USA). The temperature and humidity inside the chambers were checked throughout the exposure period. The toluene concentration in the control chamber was below the lower limit of quantification $(1 \mathrm{ppm})$. The average toluene level in the $50 \mathrm{ppm}$ chamber was $47.6 \pm 4.4 \mathrm{ppm}$.

\section{Exposure of toluene}

Mice were allotted into two main groups: mice exposed to filtered air ( $0 \mathrm{ppm}$ toluene), and mice exposed to $50 \mathrm{ppm}$ toluene in the whole body exposure chamber for $6 \mathrm{~h}$ per day, 5 days per week for 6 weeks. Each group contained twenty mice.

\section{Administration of DCS}

The mice were further divided into four different groups: 1) mice exposed to control air ( 0 ppm toluene) without DCS; 2) mice exposed to $50 \mathrm{ppm}$ toluene without DCS; 3) mice exposed to control air (0 ppm toluene) with DCS; 4) mice exposed to $50 \mathrm{ppm}$ toluene with DCS (Fig. 1B). Each group was composed of eight to nine mice. DCS (Sigma-Aldrich, Japan) was dissolved in saline and intraperitoneally injected $(20 \mathrm{mg} / \mathrm{kg}) 30 \mathrm{~min}$ before the first trial of the acquisition phase and probe trial. Control mice were given saline only.

\section{Morris water maze (MWM) behavioral test}

The animals were exposed daily to control air or toluene from 10:00 h to $16: 00 \mathrm{~h}$ for $6 \mathrm{~h}$ per day, 5 days per week for six weeks. On the day after completing the final exposure, all the animals were allowed to swim freely for $60 \mathrm{~s}$ per trial for four trials for adaptation to water, as described previously [20]. On the day after the final exposure, a MWM task was started for 5 days: 4 days for acquisition or training phase, and 1 day probe trial for memory retention. After completion of the probe trial, a visible platform test was performed on all the animals to examine visual acuity and sensorimotor activity.

The maze was a whitish gray circular pool measuring $100 \mathrm{~cm}$ in diameter and $30 \mathrm{~cm}$ in height and filled with water (temperature fixed at $25 \pm 2^{\circ} \mathrm{C}$ ). The maze was located in the laboratory room containing extra maze cues, including a colored ball, figure patterns and posters on the walls. The maze was divided into four quadrants, and the starting point for each training trial was the mid-arc of each quadrant. In the acquisition phase, the mice were given four trials per day on four consecutive days to find a hidden platform (clear transparent Plexiglas platform, $10 \mathrm{~cm}$ in diameter) located $1.0 \mathrm{~cm}$ below the water surface in the pool. A video camera and tracking system (Muromachi Kikai Co., Ltd. Japan) were used to measure the escape latency, i.e., the time required by the mouse to find and climb on to the platform. In each trial, individual mice were placed in the water facing the wall of the pool at one of the four designated starting points and left to find the hidden platform. During each trial, each mouse was given $60 \mathrm{~s}$ to find the hidden platform. If they found the platform, they were allowed to remain on it for $10 \mathrm{~s}$, and then moved from the maze to their home cage. If the mouse did not find the platform within $60 \mathrm{~s}$, it was manually placed on the platform and returned to its home cage after $15 \mathrm{~s}$. The inter-trial 
interval was at least $300 \mathrm{~s}$. The platform position remained constant on the four consecutive days. Swimming speed was also recorded throughout the acquisition phase. On day 5 , the platform was removed from the pool and a probe trial was performed to assess memory retention. Each mouse was allowed to swim for $60 \mathrm{~s}$ in the maze. The time duration that the mice spent in the target quadrant was recorded and averaged. After completion of the probe trial, a visible platform test was performed to examine visual acuity and sensorimotor activity. All the mice were tested in the maze with a visible platform (marked with colored tape) on a new location 1 $\mathrm{cm}$ above the water.

\section{Analysis of memory function-related gene expressions in the hippocampus}

To collect the total RNA from the hippocampal samples, we used a previously described protocol [21]. Briefly, total RNA extraction from the hippocampal samples was performed using the BioRobot EZ-1 and EZ-1 RNA tissue mini kits (Qiagen GmbH, Germany). Then the purity of the total RNA was examined and the quantity was estimated using the ND-1000 NanoDrop RNA Assay protocol (NanoDrop, USA). Next we performed first-strand cDNA synthesis from the total RNA using SuperScript RNase $\mathrm{H}^{-}$Reverse Transcriptase II (Invitrogen, USA), according to the manufacturer's protocol. Next we examined the hippocampal mRNA expressions of 18S, NR1, NR2A and NR2B, using a quantitative real-time RT-PCR method and the Applied Biosystems (ABI) Prism 7000 Sequence Detection System (Applied Biosystems Inc., USA). The tissue $18 \mathrm{~S}$ rRNA level was used as the internal control. Data were analyzed using the comparative threshold cycle method. Then the relative expression levels of NMDA NR1, NR2A and NR2B mRNAs were individually normalized to the $18 \mathrm{~S}$ rRNA content in the respective samples and expressed as mRNA signals per unit 18S rRNA expression.

\section{Statistical Analysis}

The results of each group were calculated and expressed as the mean \pm standard error (SE). Body weight and various organ weights were analyzed using a one-way analysis of variance (ANOVA). Data from swimming speed, acquisition phase, probe trial, and mRNA expressions of NMDA receptor subunits were analyzed using a two-way ANOVA followed by a Bonferroni post hoc test. When the main effect was significant, specific measures between groups were analyzed by Bonferroni's multiple comparison tests. A $P$ value $<0.05$ was considered statistically significant. The statistical analysis was performed using GraphPad Prism software (version5; GraphPad Software, Inc., San Diego, CA).

\section{Results}

\section{Body weight and organ weights}

To determine the general toxicity of toluene, we measured the body and organ weights of male mice at the time of sampling. Apart from the spleen, we found that the body weight and relative organ weights of the brain, thymus, lung, liver, kidney and testis were not significantly different among the control and the toluene-exposed groups with or without DCS treatment (Table 1). 
Table 1. Body weight, weight of various organs after 6 weeks toluene exposure

\begin{tabular}{lcccccccc}
\hline Group & $\begin{array}{r}\text { Body weight } \\
(\mathrm{g})\end{array}$ & $\begin{array}{r}\text { Spleen } \\
(\mathrm{mg})\end{array}$ & $\begin{array}{c}\text { Lung } \\
(\mathrm{mg})\end{array}$ & $\begin{array}{c}\text { Thymus } \\
(\mathrm{mg})\end{array}$ & $\begin{array}{c}\text { Liver } \\
(\mathrm{mg})\end{array}$ & $\begin{array}{r}\text { Kidney } \\
(\mathrm{mg})\end{array}$ & $\begin{array}{r}\text { Testis } \\
(\mathrm{mg})\end{array}$ & $\begin{array}{c}\text { Brain } \\
(\mathrm{mg})\end{array}$ \\
\hline Control & $30.15 \pm 1.20$ & $71.7 \pm 2.1$ & $45.4 \pm 0.8$ & $31.0 \pm 2.4$ & $1352.3 \pm 64.0$ & $230.1 \pm 8.3$ & $82.0 \pm 2.6$ & $448.4 \pm 4.6$ \\
C+DCS & $29.78 \pm 0.33$ & $71.2 \pm 1.9$ & $49.4 \pm 2.6$ & $35.2 \pm 2.2$ & $1368.9 \pm 19.0$ & $232.8 \pm 2.0$ & $80.8 \pm 1.5$ & $448.6 \pm 2.9$ \\
Toluene & $30.05 \pm 0.91$ & $78.8 \pm 4.8$ & $54.1 \pm 2.8$ & $34.6 \pm 1.8$ & $1399.7 \pm 69.1$ & $242.7 \pm 13.4$ & $77.7 \pm 4.8$ & $451.8 \pm 3.1$ \\
T+DCS & $30.19 \pm 0.72$ & $88.3 \pm 2.4 *$ & $51.1 \pm 1.3$ & $31.5 \pm 2.5$ & $1378.4 \pm 27.9$ & $242.9 \pm 4.9$ & $88.3 \pm 3.5$ & $451.5 \pm 7.6$ \\
\hline
\end{tabular}

Data are presented as mean \pm standard error, $*: P<0.05$ vs control, $\mathrm{C}=$ control, $\mathrm{T}=$ toluene

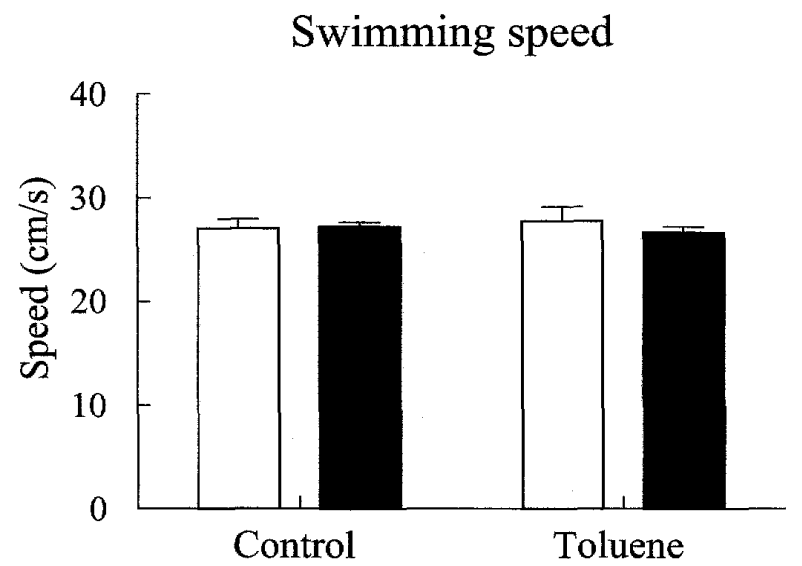

Exposure groups

Fig. 2. Swimming speed in the control and toluene-exposed mice with or without DCS treatment. Each bar represents the mean \pm S.E. $(n=8 \sim 9)$. $\square$ : DCS (-), $\mathbf{m}$ : DCS (+)

\section{Swimming speed}

The swimming speed was measured for each mouse throughout the acquisition phase and we did not observed any significant difference between the control and toluene-exposed mice with or without DCS treatment (Fig. 2).

\section{Learning performance in the control and toluene-exposed mice with or without DCS treatment}

Two-way ANOVA (treatment $\times$ day) of escape latency revealed that the main effect of treatment and the main effect of day were significant; however, the interaction of treatment versus day was not significant. Further analysis of the Bonferroni posttests showed that during the acquisition phase, there was no difference in escape latency between the control and toluene-exposed groups with or without DCS treatment on day 1 and 2. However, on day 3 and 4, the toluene-exposed 
A

Acquisition phase

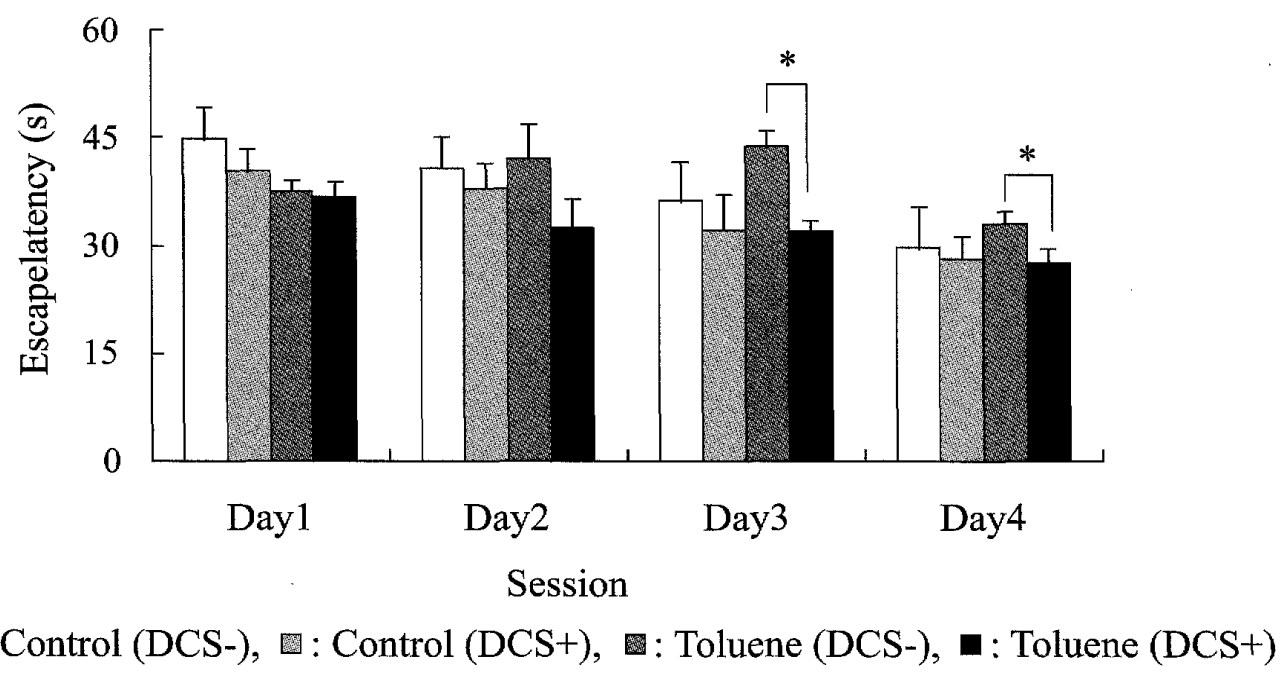

B

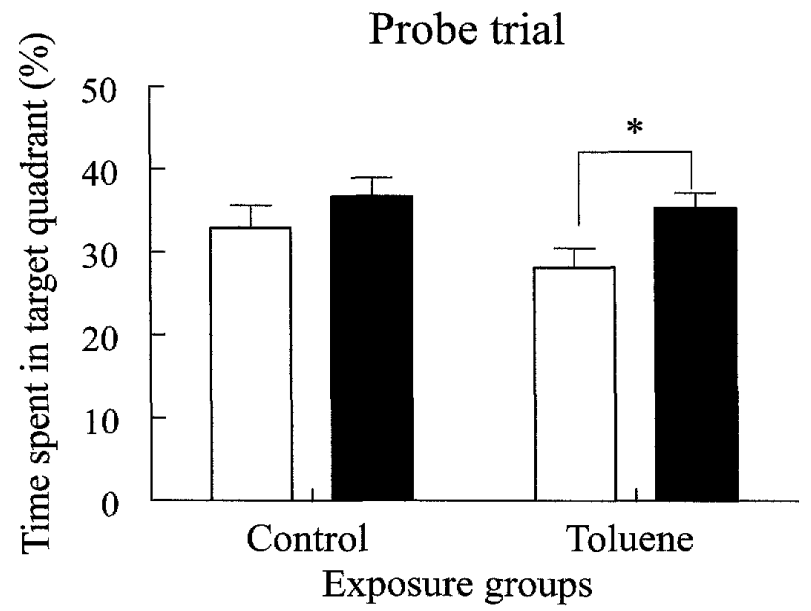

Fig. 3. A: Learning performance in acquisition phase, and B: memory retention in probe trials in the control and toluene-exposed mice with or without DCS treatment. Each bar represents the mean \pm S.E. $(\mathrm{n}=8 \sim 9)(*: P<0.05$, compared with the corresponding saline treated group). $\square:$ DCS (-), — $\operatorname{DCS}(+)$

mice with DCS treatment showed significantly better learning performance than the saline treated groups (Fig. 3A). Moreover, two-way ANOVA (DCS $\times$ toluene) of memory retention revealed that the main effect of DCS was significant; however, the main effect of toluene and the interaction of DCS versus toluene were not significant. Further analysis of the Bonferroni posttests showed that the toluene-exposed mice with DCS treatment had improved memory retention during the probe trial than saline treated groups (Fig. 3B). However, DCS did not affect spatial learning ability and memory function-related gene expression in the control mice. 

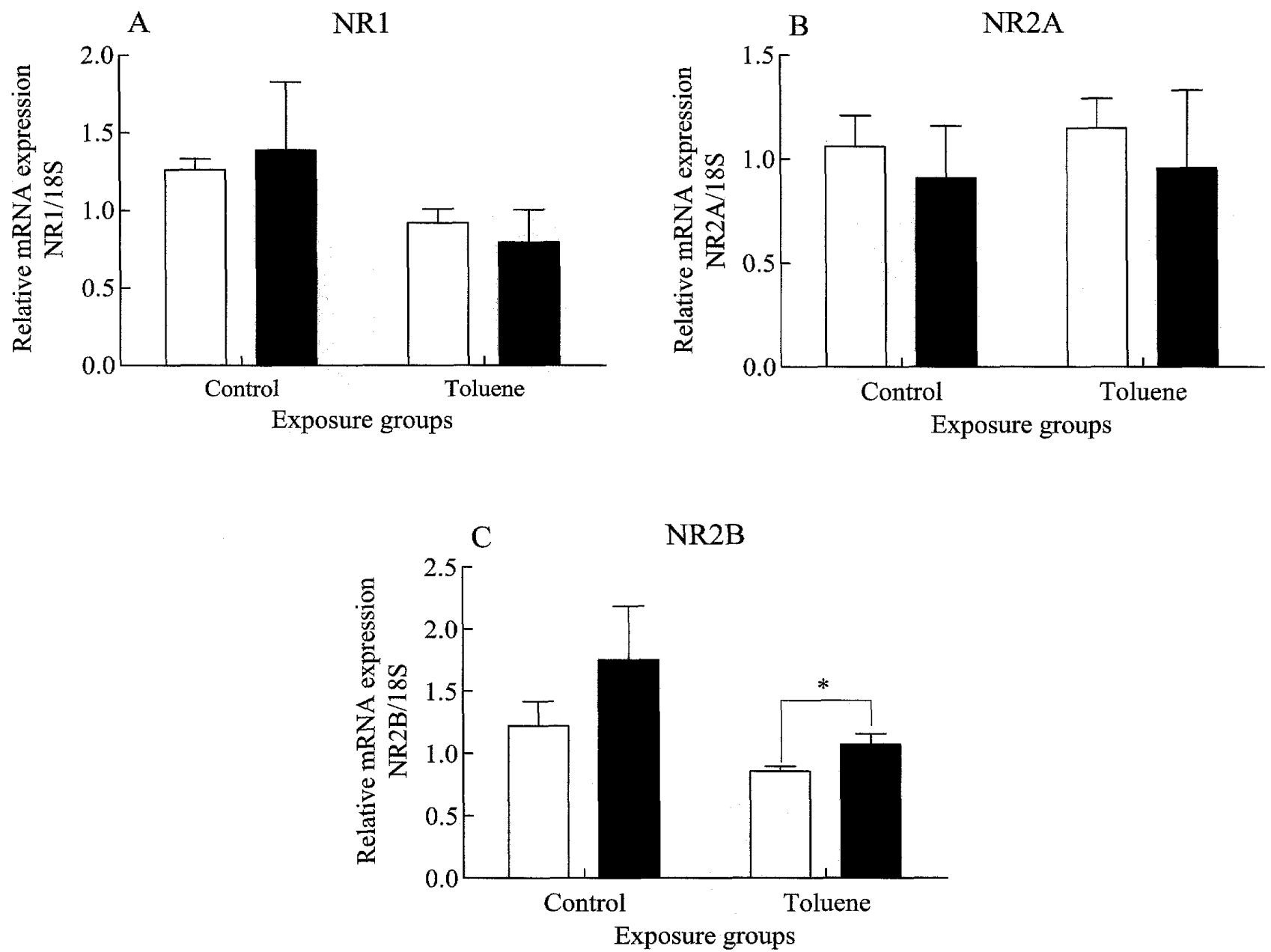

Fig. 4. Memory function-related gene NMDA receptor subunit. A: NR1, B: NR2A and C: NR2B mRNA expression in the hippocampus of the control and toluene-exposed mice with or without DCS treatment. Each bar represents the mean \pm S.E. $(\mathrm{n}=8 \sim 9)(*: P<0.05$, compared with the corresponding saline treated group). $\square:$ DCS $(-), \square:$ DCS (+)

Memory function-related gene expression in the hippocampus of the control and toluene-exposed mice with or without DCS treatment

Experimental evidence has indicated that the NMDA subtype of glutamate receptors is the most prominent ligand-gated ion channel to be affected by toluene exposure [22]. Thus, we examined the mRNA expression of NMDA subunits NR1, NR2A and NR2B in the hippocampus of the control and toluene-exposed mice with or without DCS treatment. Two-way ANOVA (DCS $\times$ toluene) of memory function-related gene expressions revealed that the main effect of DCS was significant; however, the main effect of toluene and the interaction of DCS versus toluene were not significant. Further analysis of the Bonferroni posttests showed that the mRNA expression of either NR1 or NR2A was not different between the control and toluene exposed groups and within groups after DCS treatment (Fig. 4A, B). In contrast, DCS treatment upregulated the expression of NR2B mRNA in the toluene exposed mice but not in the control mice (Fig. 4C). 


\section{Discussion}

Toluene is widely used in industrial, commercial and household products [23], and wide applications of toluene in both industrial settings and many consumer products have thus rendered the human central nervous system readily exposed to this noxious chemical, both inside and outside the home. The occupational exposure limit for toluene is $50 \mathrm{ppm}$ in Japan [4], and the recently updated threshold limit value is $20 \mathrm{ppm}$ in the United States [5]. Many reports have indicated that inhalation of low concentrations of toluene induces central neurological abnormalities in humans $[6,7]$ and a persistent deficit in spatial learning and memory in animals $[8,9]$. However, to the best of our knowledge, the manipulation of the NMDA receptor subunit while monitoring learning performance following toluene exposure has not been investigated yet. Therefore, in the present study, we showed for the first time, using a partial NMDA agonist DCS, the role of the hippocampal NMDA receptor expression in the spatial learning performance following volatile organic compound exposure in a mouse model.

The major findings of our present study were that DCS improved the spatial learning performance simultaneously with up-regulation of the NMDA receptor subunit NR2B mRNA expression in the hippocampus of mice exposed to toluene, but not in the control mice. We observed that DCS treatment enhanced learning performance in day 3 and day 4 during the acquisition or training phase and memory retention in mice exposed to $50 \mathrm{ppm}$ of toluene. However, toluene exposure did not affect body and organ weights, spatial learning ability and memory function-related gene expression in the mice hippocampus.

The NMDA receptors are heteromeric protein complexes of different subunits $\left(\mathrm{NR} 1_{\mathrm{a}-\mathrm{h}}\right.$, NR2A-D, NR3) that confer distinct biophysical properties [24]. The activation of NMDA receptors requires, in addition to the binding of amino acid neurotransmitter glutamate to NR2 and membrane depolarization, the binding of glycine or D-serine to the glycine site of NR1 $[25,16]$. Because the D-serine antagonist D-amino acid oxidase (DAO) suppresses NMDA currents and blocks hippocampal long-term potentiation (LTP) [26], this suggest that D-serine is the major endogenous co-agonist in the hippocampus and may play a role in the regulation of LTP and long-term depression (LTD).

Regarding DCS as a cognitive enhancer, previous studies have demonstrated that DCS attenuates scopolamine-induced learning and memory deficits [27] and cognitive performance following traumatic brain injury in rat models [28]. Furthermore, recent studies have shown that DCS promotes episodic-like memory [29] and accelerates the extinction of cocaine-induced condition place preference in a mouse model [30]. Experimental evidence has indicated that the NMDA receptor hypofunction mediated by low D-serine is a specific causative factor in some types of schizophrenia [31, 32]. In addition, schizophrenic behavior in rodents treated with an NMDA receptor antagonist can be partially ameliorated by D-serine [33, 34]. Duffy and colleagues demonstrated that D-serine does not improve the acquisition of spatial tasks in wild-type mice, but allows acquired information to be utilized more effectively under changing conditions [35]. Consistent with these findings, we observed that DCS did not affect working memory and memory retention in control mice with a normal brain, or enhanced memory 
retention during a probe trial in toluene-exposed mice with central neurobiological changes.

To understand the possible mechanisms of the action of toluene, our laboratory has done many supportive experiments. We have firstly indicated that the extracellular levels of neurotransmitter glutamate, a ligand for the NMDA receptor, in the mice hippocampus were rapidly and reversibly increased within $30 \mathrm{~min}$ after an acute single toluene administration (300 $\mathrm{mg} / \mathrm{kg}$, i.p.) in a dose-dependent manner, and returned to the basal level by $1 \mathrm{~h} \mathrm{[36].} \mathrm{Recently,}$ using an in vivo microdialysis study and schedule-controlled operant behavioral task, we also showed that the extracellular glutamate level was increased throughout the learning performance in the control mice while the extracellular glutamate level was decreased throughout the learning performance in mice after acute toluene administration [37]. In addition, to confirm the neurotoxic effect of toluene, we have already measured brain toluene levels by the Solid-phase microextraction technique and reported the hippocampal toluene levels following inhalation exposure [38] and intraperitoneal administration [36]. Moreover, in our previous study, we found a significant up-regulation of NMDA receptor subunit NR2B expression associated with a simultaneous induction of CaMKIV, CREB1 and FosB/ $\triangle$ FosB in the hippocampus of mice exposed to $50 \mathrm{ppm}$ toluene for 12 weeks, but not for 6 weeks [10]. The present results, which are consistent with our previous findings, indicate that the effect of toluene exposure was not observed in a 6 week exposure period; however, the remarkable effects of DCS on the spatial learning performance and the NMDA receptor subunit NR2B mRNA expression in the hippocampus were observed in mice exposed to toluene.

In conclusion, we suggest that agonism of the glycine site on the NMDA receptor appears to facilitate learning performance in a spatial task following environmental toxic chemical exposure. Further study is needed to clarify the intracellular mechanism of the neurotoxic effect of toluene at the transcription level.

\section{Acknowledgements}

We thank Ms. K. Ohnishi and S. Hirayama for their technical assistance.

\section{References}

1. Korbo L, Ladefoged O, Lam HR, Ostergaard G, West MJ \& Arlien-Søborg P (1996): Neuronal loss in hippocampus in rats exposed to toluene. Neurotoxicology 17:359-366

2. Terashi H, Nagata K, Satoh Y, Hirata Y \& Hatazawa J (1997): Hippocampal hypoperfusion underlying dementia due to chronic toluene intoxication. Rinsho Shinkeigaku 37: 10101013 (in Japanese)

3. Gelazonia L, Japaridze N \& Svanidze I (2006): Pyramidal cell loss in hippocampus of young rats exposed to toluene. Georgian Med News 135: 126-128

4. Japan Society for Occupational Health (1994): Toluene. Indust Med 36: $103-110$

5. American Conference of Governmental Industrial Hygienists (ACGIH) (2006): Threshold Limit Values and Biological Exposure Indices Guide. www.acgih.org/TLV/Studies.htm 
6. Chouaniere D, Wild P, Fontana JM et al (2002): Neurobehavioral disturbances arising from occupational toluene exposure. Am J Ind Med 41: 77-88

7. Lee YL, Pai MC, Chen JH \& Guo YL (2003): Central neurological abnormalities and multiple chemical sensitivity caused by chronic toluene exposure. Occup Med 53: 479482

8. von Euler G, Ogren SO, Li XM, Fuxe K \& Gustafsson JA (1993): Persistent effects of subchronic toluene exposure on spatial learning and memory, dopamine-mediated locomotor activity and dopamine D2 agonist binding in the rat. Toxicology 77: 223-232

9. von Euler M, Pham TM, Hillefors M, Bjelke B, Henriksson B \& von Euler G (2000): Inhalation of low concentrations of toluene induces persistent effects on a learning retention task, beam-walk performance, and cerebrocortical size in the rat. Exp Neurol 163:1-8

10. Ahmed S, Tin-Tin-Win-Shwe, Yamamoto S, Tsukahara S, Kunugita N, Arashidani K \& Fujimaki H (2007): Increased hippocampal mRNA expression of neuronal synaptic plasticity related genes in mice chronically exposed to toluene at a low-level human occupational-exposure. Neurotoxicology 28: $168-174$

11. Win-Shwe TT, Tsukahara S, Ahmed S, Fukushima A, Yamamoto S, Kakeyama M, Nakajima D, Goto S, Kobayashi T \& Fujimaki H (2007): Athymic nude mice are insensitive to low-level toluene-induced up-regulation of memory-related gene expressions in the hippocampus. Neurotoxicology 28: 957-964

12. Kutsuwada T, Kashiwabuchi N, Mori H et al (1992): Molecular diversity of the NMDA receptor channel. Nature 358(6381): 36-41

13. Monyer H, Sprengel R, Schoepfer R, Herb A, Higuchi M, Lomeli H, Burnashev N, Sakmann B \& Seeburg PH (1992): Heteromeric NMDA receptors: molecular and functional distinction of subtypes. Science 256: $1217-1221$

14. Johnson JW \& Ascher P (1987): Glycine potentiates the NMDA response in cultured mouse brain neurons. Nature 325: 529-531

15. Kleckner NW \& Dingledine R (1988): Requirement for glycine in activation of NMDAreceptors expressed in Xenopus oocytes. Science 241: 835-837

16. Clements JD \& Westbrook GL (1991): Activation kinetics reveal the number of glutamate and glycine binding sites on the N-methyl-D-aspartate receptor. Neuron 7: 605-6013

17. Crane GE (1959): Cyloserine as an antidepressant agent. Am J Psychiatry 115: 1025- 1026

18. Flood JF, Morley JE \& Lanthorn TH (1992): Effect on memory processing by D-cycloserine, an agonist of the NMDA/glycine receptor. Eur J Pharmacol 221: 249-254

19. Lanthorn TH (1994): D-cycloserine: Agonist turned antagonist. Amino Acids 6: 247-260

20. Win-Shwe TT, Yamamoto S, Fujitani Y, Hirano S \& Fujimaki H (2008): Spatial learning and memory function-related gene expression in the hippocampus of mouse exposed to nanoparticle-rich diesel exhaust. Neurotoxicology 29: 940-947

21. Win-Shwe TT, Yamamoto S, Ahmed S, Kakeyama M, Kobayashi T \& Fujimaki H (2006): Brain cytokine and chemokine mRNA expression in mice induced by intranasal instillation with ultrafine carbon black. Toxicol Lett 163: 153-60

22. Cruz SL, Mirshahi T, Thomas B, Balster RL \& Woodward JJ (1998): Effects of the abused 
solvent toluene on recombinant $\mathrm{N}$-methyl-D-aspartate and non- $\mathrm{N}$-methyl-D-aspartate receptors expressed in Xenopus oocytes. J Pharmacol Exp Ther 286: $334-340$

23. Arlien-Soborg P, Hansen L, Ladefoged O \& Simonsen L (1992): Report on a conference on organic solvents and the nervous system. Neurotoxicol Teratol 14: $81-82$

24. Monyer H, Burnashev N, Laurie DJ, Sakmann B \& Seeburg PH (1994): Developmental and regional expression in the rat brain and functional properties of four NMDA receptors. Neuron 12: $529-540$

25. Johnson JW \& Ascher P (1987): Glycine potentiates the NMDA response in cultured mouse brain neurons. Nature 325: 529-531

26. Yang Y, Ge W, Chen Y, Zhang Z, Shen W, Wu C, Poo M \& Duan S (2003): Contribution of astrocytes to hippocampal long-term potentiation through release of $\mathrm{D}$-serine. Proc Natl Acad Sci USA 100: $15194-15199$

27. Fishkin RJ, Ince ES, Carlezon WA Jr \& Dunn RW (1993): D-cycloserine attenuates scopolamine-induced learning and memory deficits in rats. Behav Neural Biol 59: 150-157

28. Temple MD \& Hamm RJ (1996): Chronic, post-injury administration of D-cycloserine, an NMDA partial agonist, enhances cognitive performance following experimental brain injury. Brain Res 741: 246-251

29. Zlomuzica A, De Souza Silva MA, Huston JP \& Dere E (2007): NMDA receptor modulation by D-cycloserine promotes episodic-like memory in mice. Psychopharmacology 193: 503 $-509$

30. Thanos PK, Bermeo C, Wang GJ \& Volkow ND (2009): D-cycloserine accelerates the extinction of cocaine-induced conditioned place preference in $\mathrm{C} 57 \mathrm{bL} / \mathrm{c}$ mice. Behav Brain Res 199: $345-349$

31. Mohn AR, Gainetdinov RR, Caron MG \& Koller BH (1999): Mice with reduced NMDA receptor expression display behaviors related to schizophrenia. Cell 98:427-436

32. Goff DC \& Coyle JT (2001): The emerging role of glutamate in the pathophysiology and treatment of schizophrenia. Am J Psychiatry 158: 1367-1377

33. Andersen JD \& Pouzet B (2004): Spatial memory deficits induced by perinatal treatment of rats with PCP and reversal effect of D-serine. Neuropsychopharmacology 29: 1080-1090

34. Lipina T, Labrie V, Weiner I \& Roder J (2005): Modulators of the glycine site on NMDA receptors, D-serine and ALX 5407, display similar beneficial effects to clozapine in mouse models of schizophrenia. Psychopharmacology 179: 54-67

35. Duffy S, Labrie V \& Roder JC (2008): D-serine augments NMDA-NR2B receptor-dependent hippocampal long-term depression and spatial reversal learning. Neuropsychopharmacology 33: $1004-1108$

36. Win-Shwe TT, Mitsushima D, Nakajima D, Ahmed S, Yamamoto S, Tsukahara S, Kakeyama M, Goto S \& Fujimaki H (2007): Toluene induces rapid and reversible rise of hippocampal glutamate and taurine neurotransmitter levels in mice. Toxicol Lett 168: 75-82

37. Win-shwe TT, Hojo R, Mitsushima D, Nakajima D, Yamamoto S \& Fujimaki H (2009): Establishment of a mouse model to assess brain neurotransmitter level and learning performance simultaneously following toxic chemical exposure: Using in vivo microdialysis 
and schedule-controlled operant behavior. J UOEH 31: 1- 11

38. Nakajima D, Tin-Tin-Win-Shwe, Kakeyama M, Fujimaki H \& Goto S (2006): Determination of toluene in brain of freely moving mice using solid-phase microextraction technique. Neurotoxicology 27: 615-618 
トルエン曝露したマウスの空間学習行動と記憶機能関連遺伝子発現へのD - シクロセ リンの影響

ウィンシュイ・ティンティン ${ }^{1}$, 影山 志保 $^{1}$, 塚原 伸治 $^{2}$, 中島 大介 $^{1}$, 藤巻 秀和 ${ }^{1}$ 1独立行政法人国立環境研究所 環境りスク研究センター, 2埼玉大学大学院 理工学研究科 生命科学部門 懪露による空間認識障害の改善に效果があるか否かC3H/HeNマウスを用いて検討し た。モりス水迷路を用いての筀間学習試験で, 水中の踏み台を捜す訓練習得段階では トルエン曝露 $(50 \mathrm{ppm}, 6$ 時間/日，6週間）をうけD-シクロセリン投与したマウスで 投与 $(20 \mathrm{mg} / \mathrm{kg})$ しないマウスょり学習効果がよくなった．踏み台を取り除いて観察 するプローブトライアルでは, やはりトルエン曝露をうけD-シクロセリン投与した マウスにおいて投与しないマウスより保持機能の改善, およびRT-PCRによるNMDA receptor subunit 2B (NR2B) 遺伝子発現の増加がみられた。本研究結果は,トルエン曝露 がNMDA受容体機能に影響を与え, D-シクロセリン投与がNR2B遺伝子を介して空間 学習機能回復に貢献している可能性を示唆している.

キーワード：トルエン, NMDA受容体, 学習行動, 海馬.

J UOEH（産業医大誌）32（2）：127－140（2010） 